\title{
PHYSICAL FITNESS AND THE LEVEL OF LEARNING BY PILOT CADETS IN THE INITIAL PERIOD OF STUDYING IN THE POLISH AIR FORCE ACADEMY (PAFA) IN DĘBLIN
}

\author{
Piotr KRAWCZYK' , Zdzisław KOBOS², Paweł MARCINKOWSKI', Robert JĘDRYS' \\ Zbigniew WOCHYŃSKI' \\ ${ }^{1}$ Polish Air Force Academy, Dęblin, Poland \\ ${ }^{2}$ Cardinal Stefan Wyszyński University, Institute of Psychology, Warsaw, Poland
}

Source of support: Own sources

Author's address: Z. Kobos, Cardinal Stefan Wyszynski University in Warsaw, Institute of Psychology, Dewajtis 5 Street, 01-815 Warsaw, Poland, e-mail: z.kobos@uksw.edu.pl

Introduction: The aim of the study is to analyze physical fitness taking into account the learning outcomes of pilot cadets of the Polish Air Force Academy.

Methods: Two groups of PAFA cadets were examined: from the second year of studies (Group I) and from the first year (Group II). The following exercise stress tests were used for the assessment of physical fitness: pull-ups, $100 \mathrm{~m}, 1000 \mathrm{~m}$ and $50 \mathrm{~m}$ swim. Analysis of the average scores obtained during the semester examination session was performed in particular score ranges of physical fitness.

Results: The obtained results show that in both examined groups, the most physically fit candidates learn at a level higher than the average score of the whole cohort population.

Conclusions: The conducted studies may provide the basis for establishing a new minimum threshold of 60 points per possible 100 points, necessary for PAFA candidates during the recruitment process.

Keywords: physical fitness, learning, pilot cadets

Figures: 2 - Tab.: 12 • References: 11 - Full-text PDF: http://www.pjambp.com • Copyright @ 2017 Polish Aviation Medicine Society, ul. Krasińskiego 54/56, 01-755 Warsaw, license WIML・Indexation: Index Copernicus, Polish Ministry of Science and Higher Education 


\section{INTRODUCTION}

Functioning in many professions, especially those related to the performance of very precise operative actions associated with aircraft piloting, requires very good health, fitness and physical performance, and predisposition to learn fast and master professional knowledge, as well as general knowledge in the field of many sciences. Such requirements are imposed, among others, on candidates for military aviation, where, in addition to technical knowledge, required is efficiency of operation both in standard conditions and in extreme stressful situations generated by the physical environment of the flight [9]. Moreover, inefficient performance of tasks in aviation professions creates health risks for both flight crew and other persons, as the aircraft travels in space and may cause collision with other aircrafts or objects on the ground [6]. Therefore, in order to prevent such negative events, a mandatory commission health assessment for aviation candidates was introduced at the beginning of the previous century. This health assessment is carried out by a multidisciplinary team of clinical medicine physicians, aeromedicine specialists and psychologists with knowledge of the conditions and the specificity of performance of the tasks during education at the airline university.

Due to the fact that aviation develops very rapidly and new aircraft designs, which allow for performance of very dynamic flights with altitude and velocity changes, are being created, both the psychophysical requirements and the knowledge necessary to operate a very complex technique are growing. This situation requires a precise assessment of the predisposition for aviation professions, taking into account both the aviation technology currently used and the technology that will have to be used after finishing education at the aviation academy. Therefore, there are many reasons why the subject of physical fitness of young people and their intellect is a subject of interest of scientists from many fields of scientific life, including physicians, psychologists and specialists in the field of physical culture. This topic is the subject of research, discussion and observation [2]. Especially since the National Health Programme, in its long-term periodic activities, put nutrition and physical activity in the first place from among the eighteen strategic objectives, and in the later decades these objectives were kept up to date $[4,5,11]$. The group of experts preparing the National Health Programme was guided by the analysis of scientific facts. These facts show that the lack of physical activity is closely related to acquisition of knowledge, learning and appropriate nutrition.

Above all, the profession of a jet-powered aircraft pilot must be performed by people who are characterized by high physical fitness as well as good physical and mental health. The main reason for this view and the requirements of high psychophysical fitness is the assumption that future professional tasks in aviation will often be performed under extreme physical and social conditions. In addition, professional activity at a high level should be maintained for about 20 years of service in combat aviation. Therefore, no selection can be carried out for the profession of pilot without identifying the right predisposers of professional success in the aviation service.

Among researchers interested in the issues of selection for aviation, the opinion prevails that intellectual performance should correlate with physical fitness of pilots $[1,8,10]$. The most recent psychomotor fitness tests $[3,8,9]$ authorize for this statement.

Due to the existing diversity of views on this topic, an attempt was made to analyze the physical fitness outcomes during recruitment as compared to the outcomes obtained by cadets during the first semester session in particular subjects.

The aim of the study was to check whether the candidates admitted to the Polish Air Force Academy with the highest number of physical fitness points will also have a high average grade from the examination session.

\section{MATERIAL AND METHODS}

The results of the recruitment of PAFA pilot cadets from years 2015 and 2016 were analyzed. 53 candidates from recruitment in 2015 (Group I) and 74 candidates from recruitment in 2016 (Group II) were examined (see Tab. 2). During the PAFA entrance examination, all persons underwent the analytical physical fitness test consisting of such elements as: pull-ups, $100 \mathrm{~m}$ dash, $1000 \mathrm{~m}$ run. The tests were carried out in sports clothes, and $50 \mathrm{~m}$ freestyle swim in a swimsuit. Time was measured with an accuracy of 0.1 second.

The tests were carried out according to the standards of physical fitness presented in Tab. 1. The indicator of the effectiveness of learning was the positive grade at the physical fitness test in the range of 30-100 points. In the analyses conducted, the average score of the exams of the first semester in 2015 (group I) was compared with the outcomes of physical fitness tests from the stage 
of recruitment to the aviation academy. Identical treatment was taken with Group II examined in 2016. The obtained results are presented in the Tab.s below.

\section{Method of testing}

$100 \mathrm{~m}$ dash - position- low start, start at sound signal.

1000 m run - position- standing position, start at sound signal.

Pull-ups - position - upper grip pull-ups, to the command "exercise" - start the exercise in such a way that after each pulling up the arms are straight in elbow joints.

$50 \mathrm{~m}$ swim - position - from the start post - start of swimming at sound signal.

\section{Statistical analysis}

The results of the performed tests were subjected to statistical analysis by calculating the arithmetic means $(M)$, standard deviation ( \pm SD) and the range of fluctuations (MIN and MAX) for individual physical fitness tests and examination grades.

Tab. 1. Criteria for men's eligibility for physical fitness in 2015 and 2016.

\begin{tabular}{|c|c|c|c|c|}
\hline \multirow[b]{2}{*}{$\begin{array}{c}\text { Points } \\
\text { of qualification }\end{array}$} & \multicolumn{4}{|c|}{ Men } \\
\hline & $\begin{array}{c}\text { Pull-ups } \\
\text { (number } \\
\text { of repetitions) }\end{array}$ & $\begin{array}{r}100 \mathrm{~m} \\
(\mathrm{sec} .)\end{array}$ & $\begin{array}{c}1000 \mathrm{~m} \\
\text { (min.) }\end{array}$ & $\begin{array}{c}50 \text { m swim } \\
\text { (sec.) }\end{array}$ \\
\hline 0 & $<5$ & $>14.0$ & $>3.46$ & \\
\hline 5 & 5 & 14.0 & 3.46 & Passage \\
\hline 6 & & & 3.45 & 110 \\
\hline 7 & 6 & 13.8 & 3.44 & 105 \\
\hline 8 & & & 3.43 & 11 \\
\hline 9 & 7 & & 3.42 & 95 \\
\hline 10 & & 13.7 & 3.41 & 90 \\
\hline 11 & 8 & & 3.40 & 85 \\
\hline 12 & & & 3.39 & 80 \\
\hline 13 & 9 & 13.6 & 3.38 & 75 \\
\hline 14 & & & 3.37 & 70 \\
\hline 15 & 10 & & 3.36 & 65 \\
\hline 16 & & 13.5 & 3.35 & 60 \\
\hline 17 & 11 & & 3.34 & 57 \\
\hline 18 & & & 3.32 & 54 \\
\hline 19 & 12 & 13.4 & 3.30 & 52 \\
\hline 20 & & & 3.28 & 50 \\
\hline 21 & 13 & & 3.26 & 48 \\
\hline 22 & & 13.3 & 3.24 & 46 \\
\hline 23 & 14 & & 3.22 & 44 \\
\hline 24 & & & 3.21 & 42 \\
\hline 25 & 15 & 13.2 & 3.20 & 40 \\
\hline
\end{tabular}

\section{RESULTS}

Comparison of somatic parameters shows that the examined persons do not differ significantly in body structure from each other (Tab. 2). The analysis of physical fitness outcomes and average semester final grades showed, in all respondents in group I, the physical fitness average expressed in points at the level of 85.37 and the average end of semester final grade of 4.14 (Tab. 3). It was observed that the examined persons, who received 100 points for physical fitness, obtained the highest average semester final grade of 4.15 (Tab. 4, Fig. 1). The research shows that cadets in group I obtained less physical fitness points and a lower average semester final grade.

Tab. 2. Age and somatic data in groups I and II.

\begin{tabular}{lcc}
\hline \multicolumn{1}{c}{ Parameter } & Group I (N-53) & Group II (N-74) \\
\hline Age /in years/ & $20 \pm 2.20$ & $20.1 \pm 2.00$ \\
\hline Body height $/ \mathrm{cm} /$ & $179.0 \pm 5.74$ & $180.0 \pm 4.00$ \\
\hline Body weight $/ \mathrm{kg} /$ & $73.6 \pm 7.60$ & $76.4 \pm 6.30$ \\
\hline BMI / & $23.0 \pm 1.71$ & $23.6 \pm 1.90$ \\
\hline
\end{tabular}

Legend: mean, \pm -standard deviation.

Tab. 3. Physical fitness and learning outcomes in a semester of the examined pilot cadets in group I (N-53)

\begin{tabular}{lcccc}
\hline \multicolumn{1}{c}{ Test } & Mean & Min. & Max. & SD \\
\hline Pull-ups /amount/ & 13.15 & 1 & 21 & 3.44 \\
\hline $100 \mathrm{~m}$ dash $/ \mathrm{s} /$ & 13.36 & 12.0 & 14.8 & 0.58 \\
\hline $1000 \mathrm{~m} \mathrm{run} / \mathrm{min} /$ & 3.18 & 2.58 & 3.46 & 0.14 \\
\hline $50 \mathrm{~m} \mathrm{swim} / \mathrm{s} /$ & 40.44 & 25.9 & 64.20 & 7.18 \\
\hline $\begin{array}{l}\text { Average points of } \\
\text { physical fitness }\end{array}$ & $\mathbf{8 5 . 3 7}$ & $\mathbf{3 3}$ & $\mathbf{1 0 0}$ & $\mathbf{1 6 . 3 6}$ \\
\hline $\begin{array}{l}\text { Average grade in } \\
\text { learning } \\
\text { in semester I }\end{array}$ & 4.14 & 3.59 & 4.76 & 0.24 \\
\hline
\end{tabular}

Legend: SD- standard deviation; arithmetic mean; Min- minimum value Max- maximum value

Tab. 4. Physical fitness and learning outcomes of pilot cadets with an average score at the level of 100 points in group I (N-13).

\begin{tabular}{lcccc}
\hline \multicolumn{1}{c}{ Test } & Mean & Min. & Max. & SD \\
\hline $\begin{array}{l}\text { Pull-ups / } \\
\text { amount/ }\end{array}$ & 15.30 & 15 & 19 & 1.10 \\
\hline $100 \mathrm{~m}$ dash $/ \mathrm{s} /$ & 13.04 & 12.40 & 13.20 & 0.24 \\
\hline $1000 \mathrm{~m} \mathrm{run} / \mathrm{min} /$ & 3.07 & 2.58 & 3.20 & 0.22 \\
\hline $50 \mathrm{~m} \mathrm{swim} / \mathrm{s} /$ & 36.20 & 27.80 & 40.00 & 3.87 \\
\hline $\begin{array}{l}\text { Average points of } \\
\text { physical fitness }\end{array}$ & $\mathbf{1 0 0}$ & $\mathbf{1 0 0}$ & $\mathbf{1 0 0}$ & $\mathbf{0 . 0 0}$ \\
\hline $\begin{array}{l}\text { Average grade } \\
\text { in learning in } \\
\text { semester I }\end{array}$ & 4.15 & 3.62 & 4.80 & 0.32 \\
\hline
\end{tabular}


Tab. 5. Physical fitness and learning outcomes of pilot cadets with an average score at the level of 94.76 points in group I ( $\mathrm{N}-13)$.

\begin{tabular}{lcccc}
\hline \multicolumn{1}{c}{ Test } & Mean & Min. & Max. & SD \\
\hline $\begin{array}{l}\text { Pull-ups / } \\
\text { amount/ }\end{array}$ & 14.69 & 11 & 21 & 2.68 \\
\hline $100 \mathrm{~m}$ dash $/ \mathrm{s} /$ & 13.07 & 12.00 & 13.50 & 0.41 \\
\hline $1000 \mathrm{~m} \mathrm{run} / \mathrm{min} /$ & 3.16 & 3.10 & 3.20 & 0.02 \\
\hline $50 \mathrm{~m} \mathrm{swim} / \mathrm{s} /$ & 38.41 & 25.90 & 47.70 & 6.47 \\
\hline $\begin{array}{l}\text { Average points of } \\
\text { physical fitness }\end{array}$ & $\mathbf{9 4 . 7 6}$ & $\mathbf{9 0}$ & $\mathbf{9 9}$ & $\mathbf{3 . 3 2}$ \\
\hline $\begin{array}{l}\text { Average grade } \\
\text { in learning in } \\
\text { semester I }\end{array}$ & 4.13 & 3.59 & 4.41 & 0.23 \\
\hline
\end{tabular}

Tab. 6. Physical fitness and learning outcomes in a semester of examined pilot cadets with an average score at the level of 84.92 points in group I (N-13).

\begin{tabular}{lcccc}
\hline \multicolumn{1}{c}{ Test } & Mean & Min. & Max. & SD \\
\hline $\begin{array}{l}\text { Pull-ups / } \\
\text { amount/ }\end{array}$ & 11.61 & 8 & 15 & 2.59 \\
\hline $100 \mathrm{~m} \mathrm{dash} / \mathrm{s} /$ & 13.19 & 12.10 & 13.80 & 0.44 \\
\hline $1000 \mathrm{~m} \mathrm{run} / \mathrm{min} /$ & 3.21 & 3.11 & 3.30 & 0.05 \\
\hline $50 \mathrm{~m} \mathrm{swim} \mathrm{/s/}$ & 40.50 & 33.40 & 50.60 & 5.81 \\
\hline $\begin{array}{l}\text { Average points of } \\
\text { physical fitness }\end{array}$ & $\mathbf{8 4 . 9 2}$ & $\mathbf{8 0}$ & $\mathbf{8 9}$ & $\mathbf{3 . 0 9}$ \\
\hline $\begin{array}{l}\text { Average grade } \\
\text { in learning in } \\
\text { semester I }\end{array}$ & 4.10 & 3.61 & 4.44 & 0.27 \\
\hline
\end{tabular}

Tab. 7. Physical fitness and learning outcomes of pilot cadets with an average score at the level of 63.50 points in group I (N-14).

\begin{tabular}{lcccc}
\hline \multicolumn{1}{c}{ Test } & Mean & Min. & Max. & SD \\
\hline $\begin{array}{l}\text { Pull-ups / } \\
\text { amount/ }\end{array}$ & 11.14 & 1 & 15 & 4.43 \\
\hline $100 \mathrm{~m} \mathrm{dash} / \mathrm{s} /$ & 14.07 & 13.30 & 14.80 & 0.48 \\
\hline $1000 \mathrm{~m} \mathrm{run} / \mathrm{min} /$ & 3.25 & 3.07 & 3.46 & 0.12 \\
\hline $50 \mathrm{~m} \mathrm{swim} / \mathrm{s} /$ & 46.17 & 35.90 & 64.20 & 8.08 \\
\hline $\begin{array}{l}\text { Average points of } \\
\text { physical fitness }\end{array}$ & $\mathbf{6 3 . 5 0}$ & $\mathbf{3 3}$ & $\mathbf{7 9}$ & $\mathbf{1 5 . 3 2}$ \\
\hline $\begin{array}{l}\text { Average grade } \\
\text { in learning in } \\
\text { semester I }\end{array}$ & 4.02 & 3.36 & 4.41 & 0.27 \\
\hline
\end{tabular}

Analysis of physical fitness outcomes and average semester final grades showed, for all examined persons in group II, the average physical fitness expressed in points at the level of 85.04 (32 - 100 points) and an average semester final grade of 4.05 (Tab. 8). It was observed that the examined persons, who received 100 points for physical fitness, obtained the highest average semester final grade of 4.06 (Tab. 9, Fig. 2). The observation of studies shows a similar tendency in the level of physical fitness and learning of cadets in group II as in group I.
Tab. 8. Physical fitness and learning outcomes of pilot cadets in group II (N-74).

\begin{tabular}{lcccc}
\hline \multicolumn{1}{c}{ Test } & Mean & Min. & Max. & SD \\
\hline $\begin{array}{l}\text { Pull-ups / } \\
\text { amount/ }\end{array}$ & 12.78 & 0 & 18 & 3.38 \\
\hline $100 \mathrm{~m}$ dash /s/ & 13.09 & 11.90 & 14.60 & 0.59 \\
\hline $1000 \mathrm{~m} \mathrm{run} / \mathrm{min} /$ & 3.20 & 2.59 & 4.04 & 0.18 \\
\hline $50 \mathrm{~m} \mathrm{swim} \mathrm{/s/}$ & 41.56 & 27.80 & 76.90 & 8.31 \\
\hline $\begin{array}{l}\text { Average points of } \\
\text { physical fitness }\end{array}$ & $\mathbf{8 5 . 0 4}$ & $\mathbf{3 2}$ & $\mathbf{1 0 0}$ & $\mathbf{1 6 . 3 0}$ \\
\hline $\begin{array}{l}\text { Average grade } \\
\text { in learning in } \\
\text { semester I }\end{array}$ & 4.05 & 2.88 & 4.61 & 0.28 \\
\hline
\end{tabular}

Tab. 9. Physical fitness and learning outcomes of pilot cadets with an average score at the level of 100 points in group II (N-9).

\begin{tabular}{lcccc}
\hline \multicolumn{1}{c}{ Test } & Mean & Min. & Max. & SD \\
\hline $\begin{array}{l}\text { Pull-ups/ } \\
\text { amount/ }\end{array}$ & 15.33 & 15 & 18 & 1.00 \\
\hline $100 \mathrm{~m}$ dash $/ \mathrm{s} /$ & 12.56 & 11.90 & 13.20 & 0.43 \\
\hline $1000 \mathrm{~m} \mathrm{run} / \mathrm{min} /$ & 3.07 & 3.02 & 3.14 & 0.04 \\
\hline $50 \mathrm{~m} \mathrm{swim} / \mathrm{s} /$ & 36.50 & 32.3 & 40.00 & 3.06 \\
\hline $\begin{array}{l}\text { Average points of } \\
\text { physical fitness }\end{array}$ & $\mathbf{1 0 0}$ & $\mathbf{1 0 0}$ & $\mathbf{1 0 0}$ & $\mathbf{0 . 0 0}$ \\
\hline $\begin{array}{l}\text { Average grade } \\
\text { in learning in } \\
\text { semester I }\end{array}$ & 4.06 & 3.69 & 4.56 & 0.24 \\
\hline
\end{tabular}

Tab. 10. Physical fitness and learning outcomes of pilot cadets with an average score at the level of 94.96 points in group II (N-31).

\begin{tabular}{lcccc}
\hline \multicolumn{1}{c}{ Test } & Mean & Min. & Max. & SD \\
\hline $\begin{array}{l}\text { Pull-ups / } \\
\text { amount/ }\end{array}$ & 14.48 & 11 & 16 & 1.06 \\
\hline $100 \mathrm{~m}$ dash $/ \mathrm{s} /$ & 12.82 & 11.90 & 13.50 & 0.39 \\
\hline $1000 \mathrm{~m} \mathrm{run} / \mathrm{min} /$ & 3.14 & 2.59 & 3.33 & 0.17 \\
\hline $50 \mathrm{~m} \mathrm{swim} / \mathrm{s} /$ & 40.77 & 27.80 & 57.10 & 5.98 \\
\hline $\begin{array}{l}\text { Average points of } \\
\text { physical fitness }\end{array}$ & $\mathbf{9 4 . 9 6}$ & $\mathbf{9 0}$ & $\mathbf{9 9}$ & $\mathbf{2 . 7 7}$ \\
\hline $\begin{array}{l}\text { Average grade } \\
\text { in learning in } \\
\text { semester I }\end{array}$ & 4.04 & 3.57 & 4.61 & 0.24 \\
\hline
\end{tabular}

Tab. 11. Physical fitness and learning outcomes of pilot cadets with an average score at the level of 80.82 points in group II (N-23).

\begin{tabular}{lcccc}
\hline \multicolumn{1}{c}{ Test } & Mean & Min. & Max. & SD \\
\hline $\begin{array}{l}\text { Pull-ups / } \\
\text { amount/ }\end{array}$ & 11.91 & 7 & 15 & 2.55 \\
\hline $100 \mathrm{~m}$ dash $/ \mathrm{s} /$ & 13.22 & 12.20 & 14.00 & 0.45 \\
\hline $1000 \mathrm{~m}$ run $/ \mathrm{min} /$ & 3.24 & 3.00 & 3.39 & 0.10 \\
\hline $50 \mathrm{~m} \mathrm{swim} / \mathrm{s} /$ & 43.13 & 32.10 & 62.10 & 8.14 \\
\hline $\begin{array}{l}\text { Average points of } \\
\text { physical fitness }\end{array}$ & $\mathbf{8 0 . 8 2}$ & $\mathbf{7 0}$ & $\mathbf{8 9}$ & $\mathbf{5 . 7 4}$ \\
\hline $\begin{array}{l}\text { Average grade } \\
\text { in learning in } \\
\text { semester I }\end{array}$ & 4.04 & 3.69 & 4.44 & 0.20 \\
\hline
\end{tabular}


Krawczyk P. et al. - Physical fitness...

Tab. 12. Physical fitness and learning outcomes of pilot cadets with an average score at the level of 53.63 points in group II (N-11).

\begin{tabular}{lcccc}
\hline \multicolumn{1}{c}{ Test } & Mean & Min. & Max. & SD \\
\hline $\begin{array}{l}\text { Pull-ups / } \\
\text { amount/ }\end{array}$ & 7.72 & 0.00 & 14 & 4.54 \\
\hline $100 \mathrm{~m}$ dash $/ \mathrm{s} /$ & 13.98 & 13.40 & 14.60 & 0.37 \\
\hline $1000 \mathrm{~m} \mathrm{run} / \mathrm{min} /$ & 3.39 & 3.18 & 4.04 & 0.23 \\
\hline $50 \mathrm{~m} \mathrm{swim} \mathrm{/s/}$ & 44.63 & 33.40 & 76.90 & 14.25 \\
\hline $\begin{array}{l}\text { Average points of } \\
\text { physical fitness }\end{array}$ & $\mathbf{5 3 . 6 3}$ & $\mathbf{3 2}$ & $\mathbf{6 9}$ & $\mathbf{1 4 . 6 1}$ \\
\hline $\begin{array}{l}\text { Average grade } \\
\text { in learning in } \\
\text { semester I }\end{array}$ & 3.83 & 2.88 & 4.26 & 0.42 \\
\hline
\end{tabular}

It was observed that the level of swimming skills is best in cadets who received 100 points on their physical fitness, while in the remaining cadets in the assumed score ranges, it is directly proportional to their physical fitness (Fig. 1 and Fig. 2).

\section{DISCUSSION}

Obtained results of the presented studies showed that the physical effort of cadets stimulates cognitive processes, which is proved by the results of the examination session in an airline university. Analysis of the results also showed that cadets who received 100 points from physical fitness during the recruitment process and an average semester score not lower than the whole group in 2015 and 2016 (Tables 4 and 9). It should be stressed that the first group had a significantly lower number of respondents than the second group, which could have had an impact on better selection in 2015. In group I, it was observed that in cadets who received 100 points on physical fitness during recruitment, their dominant skills were strength and endurance tests (Tab. 4). And in group II these were strength, endurance and speed tests (Tab. 9). This fact is significant as an important criterion in the selection of candidates for aviation, since these characteristics are based on genetic factors. It can be said that learning and acquiring knowledge is related to increased awareness of cadets of the role of physical fitness in the military pilot profession. Our observations correspond to the research of other authors $[1,8]$.

The analysis of the physical fitness outcomes expressed in reference points as average grades on learning in the first semester suggests that the lower point threshold of physical fitness during recruitment in 2015 and 2016 (30 points out of possible 100 points), as a selection criterion, is far too low. Tables 7 and 12 show that it would be justified to raise the lower threshold to 60 points. Too wide a discrepancy between the selection criterion for physical fitness and academic achievement is linked to the problems within the scope of practical aviation (pilotage). The newest method of psychomotor evaluation of a pilots shows that pilots must maintain a balance between thinking and psychomotor efficiency in temporary criteria

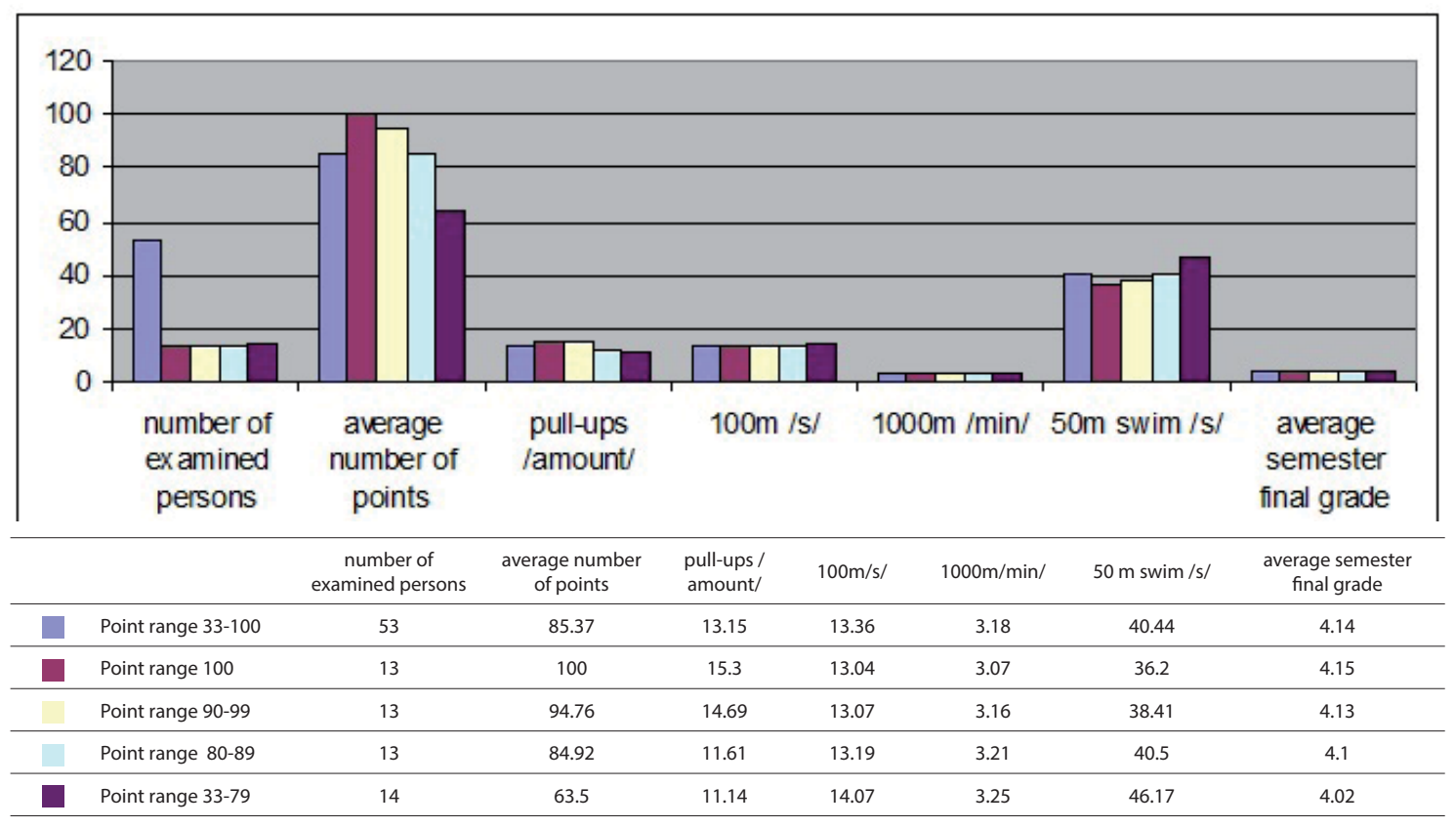

Fig. 1. Physical fitness and learning outcomes in group I. 


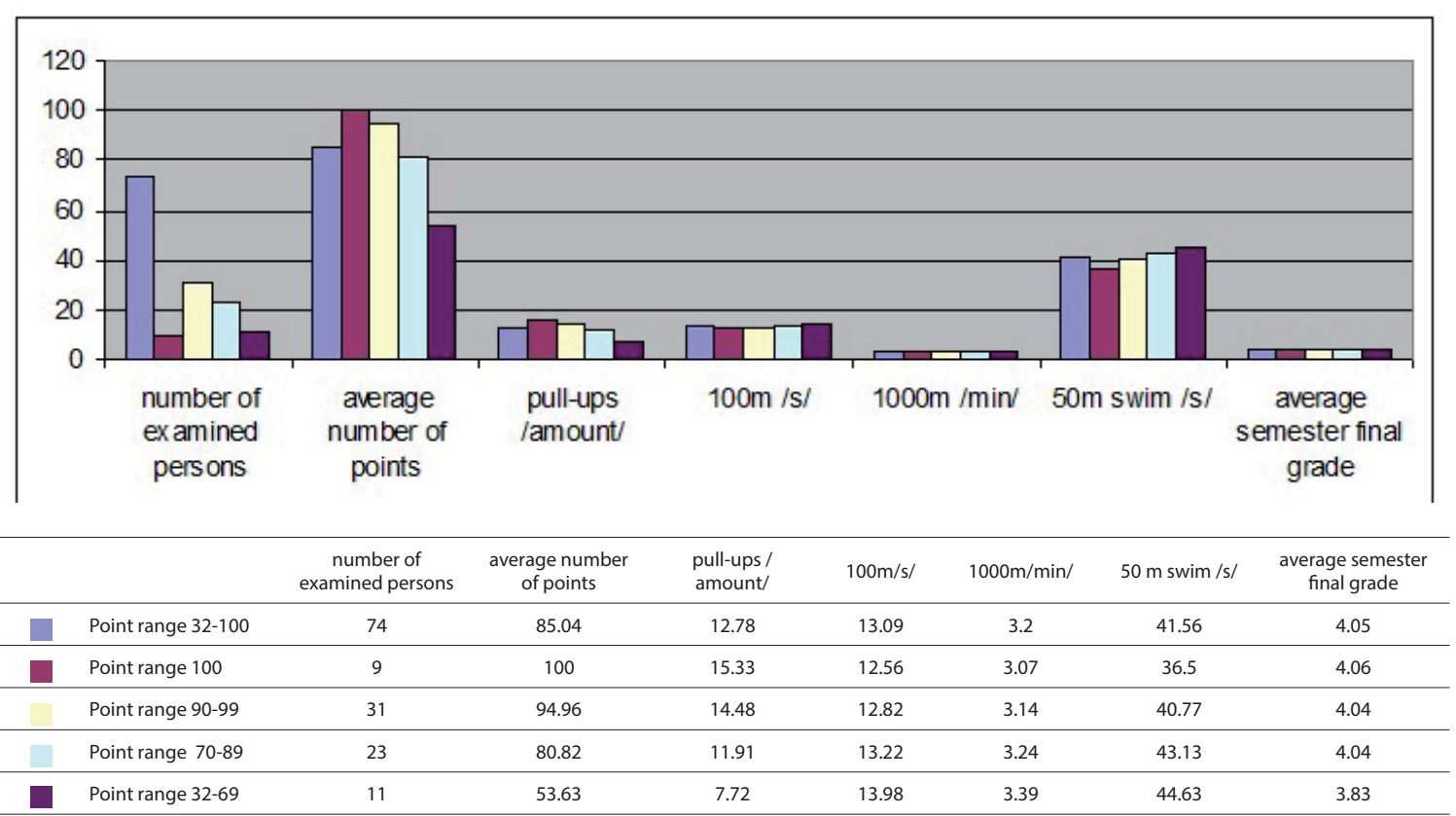

Fig. 2. Physical fitness and learning outcomes in group II.

in extreme conditions of their working environment [10]. Hence, the physical fitness of pilot cadets in the training process should not be very diversified. This is a basic condition for a highquality psychomotor training of cadets.

In this study, which proves the urgent need for modification of the selection of candidates for aviation, a modern system of cadet training should be taken into account. As well as the selection of motor types, on which the effect of training depends.

The study found that endurance-power motor type is beneficial for aviation [10]. Cadets from both examined groups, who received the maximum number of points (100 points) on physical fitness, together with the highest average semester final grades in relation to the rest of the examined persons, determine the direction of selection of candidates for aviation.

\section{CONCLUSIONS}

The observations in both recruitments show that in the fittest candidates the level of learning is slightly higher than the average grade of the whole examined population.

The conducted studies are the basis for establishing a new minimum point threshold of 60 points per possible 100 points for PAFA candidates during the recruitment process.

\section{AUTHORS' DECLARATION:}

Study Design: Piotr Krawczyk, Zdzisław Kobos, Paweł Marcinkowski, Robert Jędrys, Zbigniew Wochyński; Data Collection: Piotr Krawczyk, Zdzisław Kobos, Paweł Marcinkowski, Robert Jędrys, Zbigniew Wochyński; Manuscript Preparation: Zdzisław Kobos, Robert Jędrys, Zbigniew Wochyński; Funds Collection: Robert Jędrys, Zbigniew Wochyński; The Authors declare that there is no conflict of interest. 
Krawczyk P. et al. - Physical fitness...

\section{REFERENCES}

1. Castelli DM, Hillman ChH, Buck SM, Erwin HE, Physical fitness and academic achievement in third-and fifth-grade students, Journal of Sport and Journal of Sport \& Exercise Psychology; 2007; 29: 239-252.

2. DeVoge JM, Bass EJ, Job-Specific or General Training: A Quantitative Assessment; The International Journal of Aviation Psychology; 2007; 17(4): 333-351.

3. Gayles JG, Hu s, , The influence of student engagement and sport participation on college outcomes among division I student athletes; The Journal of Higher Education; 2016; 80: 315-333.

4. Narodowy Program Zdrowia 1996-2005, Warszawa; Ministerstwo Zdrowia i Opieki Społecznej;1996.

5. Narodowy Program Zdrowia 2007-2015, Warszawa; Ministerstwo Zdrowia i Opieki Społecznej; 2007.

6. O'Hare D, Cognitive Functions and Performance Shaping Factors in Aviation Accidents and Incidents; The International Journal of Aviation Psychology; 2006; 16(2):145-156.

7. Terelak JF, Człowiek w sytuacji pracy w okresie ponowoczesności; Warszawa; Wyd. Naukowe UKSW; 2011.

8. Trudeau F, Shephard RJ, Physical education, school physical activity, school sports and academic performance, International Journal of Behavioral Nutrition and Physical Activity; 2008; 40: 5-10.

9. Wochyński Z, Skrzyńska J, Jędrys, R, Kobos Z, Assessment of physiological indicators and psychomotor predictors in cadets before and after a half-year training in practical flying an aircraft in the air. 63rd International Congress of Aviation and Space Medicine, Oxford, UK. 20 - 24 September 2015.

10. Wochyński Z, Skrzyńska J, Pilaczyński P, Jędrys R, Kobos Z, The impact of motor predispositions in pilot cadets upon the results of ASET timings.65rh International Congress of Aviation and Space Medicine, Rome,10-14 September 2017.

11. Wojtyniak B, Goryński P, Kuszewski K, Wysocki MJ, Sytuacja zdrowotna ludności Polski w aspekcie oczekiwanych efektów realizacji Narodowego Programu Zdrowia: Zdr. Publ.; 2005; 115(2): 125-131.

\section{ACKNOWLEDGEMENTS}

The views, opinions, and findings contained in this article are our own and should not be construed as an official Polish Air Force position, policy, or decision, unless so designated by other official documentation.

Cite this article as: Krawczyk P, Kobos Z, Marcinkowski P, Jędrys R, Wochyński Z. Physical Fitness and The Level of Learning by Pilot Cadets in the Initial Period of Studying in the Polish Air Force Academy (Pafa) In Dęblin. Pol J Aviat Med Bioeng Psychol 2017; 23(1): 15-21. DOI: $10.13174 /$ pj ambp. 19.06.2018.02 